\title{
EL DERECHO FRENTE A LA PANDEMIA DEL CORONAVIRUS COVID-19
}

Desde finales del año 2019 la humanidad tuvo que enfrentar una de las peores pandemias desde la denominada gripe española -que dejó millones de muertos a comienzos del siglo XX-, a raíz del surgimiento de una nueva especie coronavirus que al parecer saltó de alguna especie de murciélago hacia el ser humano.

Si bien los coronavirus son una extensa familia de virus que causan infecciones respiratorias que pueden ir desde el resfriado común hasta enfermedades más graves como el Síndrome Respiratorio Agudo Severo (SRAS), el coronavirus descubierto por un brote en Wuhan (China) en diciembre de 2019, tiene la particularidad de engañar al sistema inmunológico del ser humano que no lo puede detectar cuando ingresa al cuerpo. Una vez invade al individuo, lo puede transmitir fácilmente a otros sin que sepa que es portador por lo que se hace difícil su detección (OMS, 2020).

Fue denominado COVID-19 por la abreviatura "CO" correspondiente a "corona", "VI" a "virus" y "D" a "disease" ("enfermedad") y 19 por el año de su aparición. El COVID19 se caracteriza por ser una enfermedad infecciosa ocasionada por el virus SARSCoV-2 (coronavirus del síndrome respiratorio agudo grave tipo 2), que si bien en la mayoría de las personas que se contagian pueden tener síntomas de intensidad leve o moderada y se recuperan sin necesidad de hospitalización, en otros casos puede ser fatal y causar complicaciones respiratorias que pueden llevar a la muerte al contagiado.

Debido a esta situación a todas luces extraordinaria, buena parte de los Estados del mundo declararon estados de excepción o de emergencia sanitaria, lo cual les permitió adoptar medidas extraordinarias para combatir al nuevo enemigo invisible y tratar de aminorar el impacto en sus economías.

Declarar el estado de emergencia tiene consecuencias de gran alcance para todos los ciudadanos, sobre todo porque los derechos básicos se suspenden con frecuencia en caso de emergencia. Pero declarar dicho estado también tiene efectos profundos para el equilibrio de poderes dentro del gobierno: el poder tanto del legislativo como del judicial suele reducirse en beneficio del ejecutivo. 
Una interpretación caritativa de por qué los gobiernos llaman estados de emergencia sería, por lo tanto, que los poderes adicionales otorgados por la constitución son necesarios para actuar con rapidez y la debida diligencia para salvar a las personas y aliviar las consecuencias sociales y económicas de las emergencias.

Pero un gobierno también puede declarar un estado de emergencia porque está ansioso por utilizar los poderes adicionales en su propio favor, por ejemplo, para debilitar a su oposición política. Como tal, los estados de excepción pueden ser convocados por razones no asociadas con emergencias reales, sino como una herramienta para mejorar las posibilidades de permanecer en el cargo o para implementar políticas que de otro modo estarían bloqueadas.

La crisis vivida por casi todos los países del mundo en el año 2020 por cuenta de la pandemia del coronavirus Covid-19 y el impacto directo e indirecto en casi todas las actividades humanas, se ha proyectado en diversos campos como el económico, el social, el cultural, el ambiental, entre otros.

El derecho obviamente no escapa de esta afectación y es aquí donde encontramos muchos aspectos problemáticos que deben ser discutidos por la academia, con el fin de debatirlos y proponer respuestas a los múltiples interrogantes que hoy día plantea la ciencia jurídica.

Todos los países del mundo sin excepción se han visto afectados por esta pandemia. Sus gobiernos han debido actuar de diversas maneras con el fin de hacerle frente a este virus letal que, sin armas de destrucción masiva, está aniquilando los medios de producción, los empleos y las economías de varios Estados y ha puesto en entredicho la eficacia del derecho frente a situaciones extraordinarias como las pandemias.

Para plantear algunas problemáticas que han surgido bajo este apocalíptico panorama, tenemos la aplicación de los regímenes de excepción en los sistemas constitucionales que lo prevén, el control judicial y político a las actuaciones del ejecutivo, la limitación y en muchos casos la sistemática vulneración de derechos fundamentales, la respuesta eficaz de la constitución a las emergencias sanitarias, entre muchas otras.

El primero de estos cuestionamientos lo plantea las decisiones generalizadas de muchos países, incluidas las democracias liberales, que han tomado medidas 
extraordinarias que sin duda alguna serían constitucionalmente problemáticas en tiempos normales.

El otro tema de debate que ha surgido en esta emergencia sanitaria mundial ha sido la afectación sistemática de los derechos fundamentales. Si bien existen fuertes justificaciones para tales restricciones como evitar la propagación del virus, la saturación del sistema de salud y la muerte de los contagiados, actualmente se debaten los límites a estas imposiciones y la debida respuesta de los Estados constitucionales a las necesidades de sus ciudadanos.

En este punto, nacen posibles contradicciones, pues bajo el argumento de proteger a la comunidad del coronavirus, se están menoscabando otros derechos esenciales, sin los cuales es imposible subsistir dignamente.

Derechos como la libre locomoción, la salud, el trabajo, la educación, la alimentación, la vida digna, entre muchos otros, son algunos de los derechos restringidos -y en varios casos anulados-, que los colombianos debieron soportar con la firme convicción de evitar un mal mayor.

Las constituciones políticas en los Estados contemporáneos prevén un modelo para el estado de normalidad del respectivo estado, el cual crea sus instituciones de acuerdo a su tradición política o según la importancia a ciertos aspectos que desean incluir, como por ejemplo un largo listado de derechos fundamentales o la creación de instituciones que son consideradas importantes para esa sociedad.

En el mismo sentido, un buen grupo de constituciones prevé todo un sistema de estados de excepción que puede ser aplicado en estados de anormalidad, cuando se altera el funcionamiento Estado democrático o nacen situaciones extraordinarias que requieren medidas especiales que no pueden ser enfrentadas con los artículos de la constitución.

Sin embargo, debe existir un límite y un continuo control a las decisiones gubernamentales que limitan los derechos en plena pandemia, pues incluso en los casos más extremos, debe continuar rigiendo el Estado de derecho.

Se hace necesario que el sistema de pesos y contrapesos funcione completamente y que el control a los actos del Gobierno sea realizado plenamente por la Corte Constitucional y Consejo de Estado, así como el debate político por parte del 
Congreso de la República. En estos momentos es cuando se pone a prueba una verdadera democracia.

Germán Alfonso López Daza (PhD). Editor Revista Jurídica Piélagus 